\title{
Pediatrics Consequences of Caesarean Section-A Systematic Review and Meta-Analysis
}

\author{
Aneta Słabuszewska-Jóźwiak ${ }^{1, *}$, Jacek Krzysztof Szymański ${ }^{1}$, Michał Ciebiera ${ }^{2}$, \\ Beata Sarecka-Hujar ${ }^{3}$ (i) and Grzegorz Jakiel ${ }^{1}$ (i) \\ 1 First Department of Obstetrics and Gynaecology, Centre of Postgraduate Medical Education, \\ Żelazna 90 Street, 01-004 Warsaw, Poland; jkszymanski2@gmail.com (J.K.S.); grzegorz.jakiel1@o2.pl (G.J.) \\ 2 Second Department of Obstetrics and Gynaecology, Centre of Postgraduate Medical Education, \\ Cegłowska 80 Street, 01-809 Warsaw, Poland; michal.ciebiera@gmail.com \\ 3 Department of Basic Biomedical Science, Faculty of Pharmaceutical Sciences in Sosnowiec, \\ Medical University of Silesia in Katowice, Kasztanowa 3 Street, 41-200 Sosnowiec, Poland; \\ beatasarecka@poczta.onet.pl \\ * Correspondence: anetaslabuszewska@gmail.com; Tel.: +48-504-187-297
}

Received: 13 September 2020; Accepted: 29 October 2020; Published: 31 October 2020

\begin{abstract}
Background: Cesarean section is a surgical procedure, which is the most frequently performed in gynecology and obstetrics. It is commonly believed that an operative delivery is a less painful and safer mode of delivery, which translates into an increasing number of the procedures performed without medical indications. The maternal sequelae of cesarean sections are well elucidated and widely discussed in the literature, while long-term neonatal consequences still remain the issue of research and scientific dispute. The aim of the present paper was to perform a systematic review of current literature regarding pediatrics consequences of cesarean section. Methods: We reviewed available data from PubMed, Science Direct as well as Google Scholar bases concerning early and long-term neonatal sequelae of operative deliveries. The following key words were used: "cesarean section", "caesarean section", "neonatal outcomes", "respiratory disorders", "asthma", "obesity", "overweight", and "neurological disorders". A total of 1636 papers were retrieved out of which 27 were selected for the final systematic review whereas 16 articles provided data for meta-analysis. Statistical analyses were performed using RevMan 5.4. To determine the strength of association between the caesarean section and respiratory tract infections, asthma, diabetes type 1 as well as obesity the pooled odds ratios (OR) with the $95 \%$ confidence intervals (CI) were calculated. Results: Conducted meta-analyses revealed that caesarean section is a risk factor for respiratory tract infections (pooled $\mathrm{OR}=1.3095 \% \mathrm{CI} 1.06-1.60, p=0.001$ ), asthma (pooled OR $=1.2395 \% \mathrm{CI} 1.14-1.33, p<0.00001$ ) as well as obesity (pooled OR $=1.3595 \%$ CI 1.29-1.41, $p<0.00001$ ) in offspring. Conclusions: The results of the studies included indicated that children delivered by cesarean section more commonly developed respiratory tract infections, obesity and the manifestations of asthma than children delivered vaginally. The risk of developing diabetes mellitus type 1 or neurological disorders in offspring after caesarean section is still under discussion.
\end{abstract}

Keywords: caesarean section; neonatal outcomes; respiratory disorders; asthma; obesity; overweight; neurological disorders

\section{Introduction}

Cesarean section is the most common surgical procedure performed in women worldwide. Notably, a high percentage of surgical deliveries did not translate into reduced maternal or neonatal mortality [1-5]. According to the recommendations of the World Health Organization (WHO) the 
rates of cesarean sections should range between 10 and 15\% [6]. However, the fear of labor pains and simultaneous concern about the baby to be born, are more and more commonly leading to women choosing to deliver by cesarean section $[7,8]$. The probability of complications secondary to the implemented procedure increases with the increasing percentage of cesarean sections. Globally, perinatal mortality rates reach 19 out of 1000 children [9]. As regards African countries-1 in 23 neonates dies as a consequence of cesarean section [10], while in developed countries it is believed that the procedure may prevent severe perinatal complications.

According to an increasing number of epidemiologic studies, children delivered by cesarean section more commonly developed respiratory and neurological disorders (e.g., autism spectrum disorders [11], schizophrenia [12]) and immune-related diseases, such as asthma [13,14], skin atopy [15], juvenile arthritis, coeliac disease [16], type 1 diabetes (T1D) [17] or obesity [1,18-23]. It is worth noting differences between the occurrence of the above-mentioned conditions in cases when the surgical procedure was performed after delivery had started.

Hypothetical Mechanisms of the Influence of Cesarean Section on Neonatal Status

Perinatal stress leads to the increased production of catecholamine and cortisol in the infant's blood [21]. It is important for the development of pulmonary maturity [24] and the adaptation of the circulatory system to extrauterine life [25]. The completion of pregnancy without associated neonatal stress (i.e., in case of an elective cesarean section) is a potential factor which may interfere in those processes. Schuller et al. claimed that neonates delivered vaginally were characterized by higher cortisol levels and presented higher expression of pain compared to children delivered by cesarean section [26]. In the case of infants delivered by cesarean section, the level of cortisol measured in the umbilical cord blood was significantly lower compared to vaginally delivered neonates [27-29] or to vacuum-assisted delivery [30], which might result in the increased percentage of adaptation complications, such as respiratory distress syndrome (RDS), persistent tachypnea or pulmonary hypertension which require hospitalization in the neonatal intensive care unit (NICU). In turn, prolonged NICU stay may be associated with a higher risk of the implementation of iatrogenic procedures $[31,32]$ and longer total postnatal hospitalization. Delivery-related stress causes the activity of various cytokines, therefore changes in this process may have impact on the developing immune system. In the Taiwanese study, Liao et al. [22] reported also that TNF- $\alpha$ and IL-6 response toward TLR1-2 stimulation was significantly reduced in CS delivered neonates than in those delivered vaginally (Figure 1).

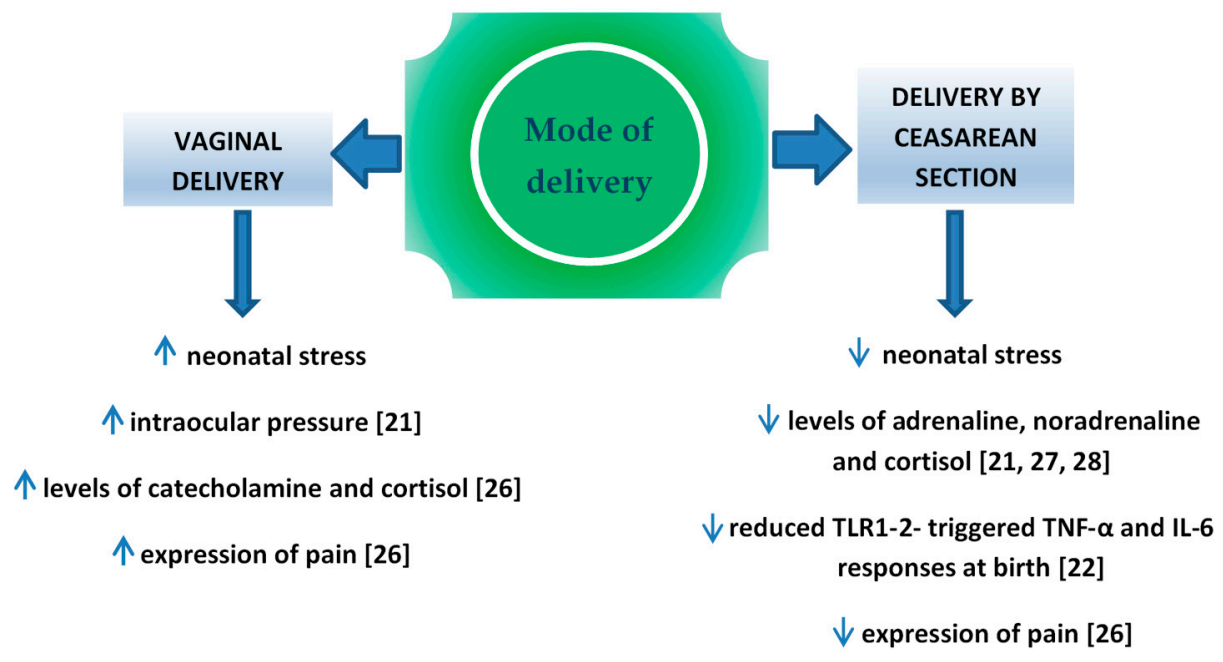

Figure 1. Factors influence on fetus, depend on mode of delivery.

The disturbed colonization with bacterial microflora within the skin and digestive tract was the reason for a more frequent occurrence of immune diseases in children delivered by cesarean section [33]. The possibility of the transfer of those bacteria to the neonatal digestive tract is higher in 
case of long-term contact with the vaginal flora during vaginal delivery [34]. An increasing number of authors emphasized the contribution of maternal rectal microbiome to the optimal colonization of neonates [35,36]. The colonization is also promoted by $\mathrm{pH}$ in the stomach of neonates, which thanks to the swallowing of the amniotic fluid in utero, becomes neutral and provides conditions for the survival of aspirated bacteria. Lactobacillus, Bifidobacterium and Bacteroides are the dominant species of intestinal bacteria occurring at the early postnatal period in vaginally delivered neonates [34]. The bacteria play an important part in the regulation of the immune system [37] influencing the level of NK (natural killer) cells [38], regulating the population of T lymphocytes [39,40] the secretion of IgA antibodies [41], and the synthesis of proinflammatory cytokines [42-44]. Lactobacillus bacteria may prevent airway hyperresponsiveness by limiting the presence of inflammatory cells in the peribronchial tissue [45], while Bifidobacterium species prevents intestinal necrosis and plays a role in the regulation of the body weight of an infant [46,47]. Numerous authors emphasized both quantitative and qualitative differences in the intestinal microflora depending on the mode of delivery completion. It was reported that the meconium of neonates delivered by cesarean section included reduced amounts of Lactobacillus, Bifidobacterium, Bacteroides and Prevotella bacteria, while the dominant ones included iatrogenic bacterial species or ones which colonized the skin, i.e., Staphylococcus [34], Streptococcus [48], Klebsiella, Enterococcus and Clostridium [49]. Bifidobacterium species, responsible for the synthesis of short-chain fatty acids (SCFA), undergo a relatively rapid elimination from the digestive tract of neonates delivered by cesarean section [34]. SCFAs are a type of communicators between the microbiome and the immune system contributing to the maintenance of balance between pro- and anti-inflammatory reactions, e.g., by transferring the signal with a group of $\mathrm{G}$ protein-coupled receptors (GPR), which are present not only on the cells of the gastrointestinal system, but also of the immune and nervous system. It is believed that SCFAs may modulate the weight and reduce the amount of consumed food by the stimulation of enteroendocrine $L$ cells responsible for releasing peptide $Y Y$ (PYY) and glucagon-like peptide 1 (GLP-1) [50]. Therefore, they may influence the body weight of neonates. However, the role of bacterial microflora is still ambiguous in the development of type 1 diabetes [51].

Numerous authors of epidemiological studies emphasized a correlation between environmental factors influencing the fetus prenatally and over the early postnatal period and the development of circulatory system diseases, diabetes, obesity, tumors [52-55] and schizophrenia [56] in adulthood. The Epigenetic Impact of Childbirth (EPIIC) study demonstrated that the use of oxytocin, antibiotics and cesarean section may lead to long-term health implications [57]. The authors suspected that epigenetic mechanisms which influenced gene expression modification might be responsible for the phenomenon [57]. DNA methylation is a well elucidated epigenetic mechanism. It consists in adding a methyl group to cytosine-5-carbon in a reaction catalyzed by deoxyribonucleic acid methyltransferase (DNMT). CpG island hypermethylation within a gene promoter most commonly results in the reduction or inactivation of its expression [58,59]. Research showed that tobacco smoking, malnutrition, and long-lasting maternal stress during pregnancy might lead to silencing the expression of some genes in the fetus resulting in a variety of clinical consequences [60-62]. According to some researchers, cesarean section changed the global DNA methylation and the methylation of individual genes. Schlinzing et al. demonstrated a higher global methylation in the leukocytes of the umbilical cord blood in a group of elective cesarean sections [63] while Słabuszewska et al. showed a significantly lower global methylation of DNA in the placenta of women following a cesarean section [64]. Franz et al. found no differences in the global methylation of DNA between vaginal deliveries and cesarean sections, although the methylation of individual genes was significantly higher in neonates delivered by cesarean section [65]. Notably, the above mentioned studies vary in terms of methodology which may contribute to differences in the results. Therefore, the issue of the influence of cesarean section on changes in DNA methylation and its clinical implications still remains the subject of research. 
Therefore, we decided to review current literature concerning pediatrics consequences of cesarean section, because of a high percentage of elective cesarean sections and numerous studies providing mutually exclusive conclusions regarding possible neonatal complications following surgical deliveries.

\section{Material and Methods}

This systematic review was conducted in accordance with the Preferred Reporting Items for Systematic Reviews and Meta-Analyses (PRISMA) guideline.

\subsection{Search Strategy}

We searched PubMed, Science Direct databases for relevant papers published from 2008 to 2020 (last search August 2020). The title and abstract of the studies were screened following inclusion/exclusion criteria. Furthermore, a hand-search of the reference sections of relevant previous reviews along with reference lists of studies meeting the inclusion criteria was also conducted. The identified studies were included in accordance with the Population, Intervention, Comparison, Outcomes (PICO) model in order to select the relevant research question in the selection criteria.

- Population: newborns and children who have delivered via cesarean section

- Intervention: cesarean section

- Comparison: any mode of delivery where reported

- Outcomes: respiratory diseases, asthma, obesity, overweight, diabetes mellitus type 1, neurological disorders

The only limits applied were the date (original reports published from 2008 to 2020; review papers and meta-analyses published from 2010 to 2020) and the language (available in English).

\subsection{Statistical Analyses}

Statistical analyses were performed with the use of Review Manager software (RevMan version 5.4 Cochrane, London, UK). To determine the strength of association between the caesarean section and respiratory tract infections, asthma, diabetes mellitus type 1 as well as obesity the pooled odds ratios (OR) with the $95 \%$ confidence intervals $(\mathrm{CI})$ were calculated. For caesarean section events we took into account both emergency and elective caesarean sections whereas vaginal delivery covers both unassisted and assisted vaginal delivery. To assess the degree of heterogeneity between included studies, the $\mathrm{I}^{2}$ is calculated. It describes the proportion of variance (from $0 \%$ to $100 \%$ ), which is due to variance in true effect sizes rather than sampling error. It is assumed that in the case of significant heterogeneity between studies, the random effects method (DerSimonian-Laird) should be used to calculate the pooled OR with the $95 \% \mathrm{CI}$ whereas in the case of nonsignificant heterogeneity, the calculation should be performed with fixed effects method (Mantel-Haenszel). Since random-effect model is supposed to provide a more conservative OR estimation than fixed model, by representing the mean association in the populations, the results of random effect model are only demonstrated in our study. To assess potential publication bias, Egger's regression and Begg's rank correlation were performed. In addition, to evaluate the stability of the results, sensitivity analyses were made by sequential exclusion of each study.

The obtained results of the present meta-analysis were summarized in tables as well as illustrated using forest plots.

\section{Results}

\subsection{Study Selection Process}

In total 19,175 articles were initially identified. For the initial screening, 3425 duplicates were identified and removed, leaving 15,750 articles. Titles and abstracts, were then assessed by two researchers, with this process ending with the inclusion of 1636 articles. Full texts were then retrieved 
for those citations considered potentially relevant and assessed for eligibility by the two researchers. Of these 1636 articles, 1479 were excluded. The most common reason for exclusion was preterm delivery, instrumental delivery, the small number of participants and language other than English. Reference lists of included studies were hand searched by the first author and a further 2 articles were subsequently included. Separate searches were performed for each of the topics covered in this review. For the first elimination step, studies that were clearly not relevant based on the title were removed. Then, duplicates were removed. Next, the remaining abstracts were reviewed and those not relevant to the topic were removed. For all the remaining papers, the full text of the paper was read to determine whether relevant information was included.

Eventually, a total of 27 relevant articles [11,20,66-89] were included in the current systematic literature review. A summary of the search process is illustrated in Figure 2, as recommended by the PRISMA guidelines [90]. Due to sufficient data regarding the occurrence of respiratory tract infections, asthma, overweight/obesity as well as diabetes mellitus type 1, 16 articles $[11,20,67,68,70-81,85,86,88,89]$ were included in the meta-analysis. Results of the statistical tests are presented in Figures 3-6.
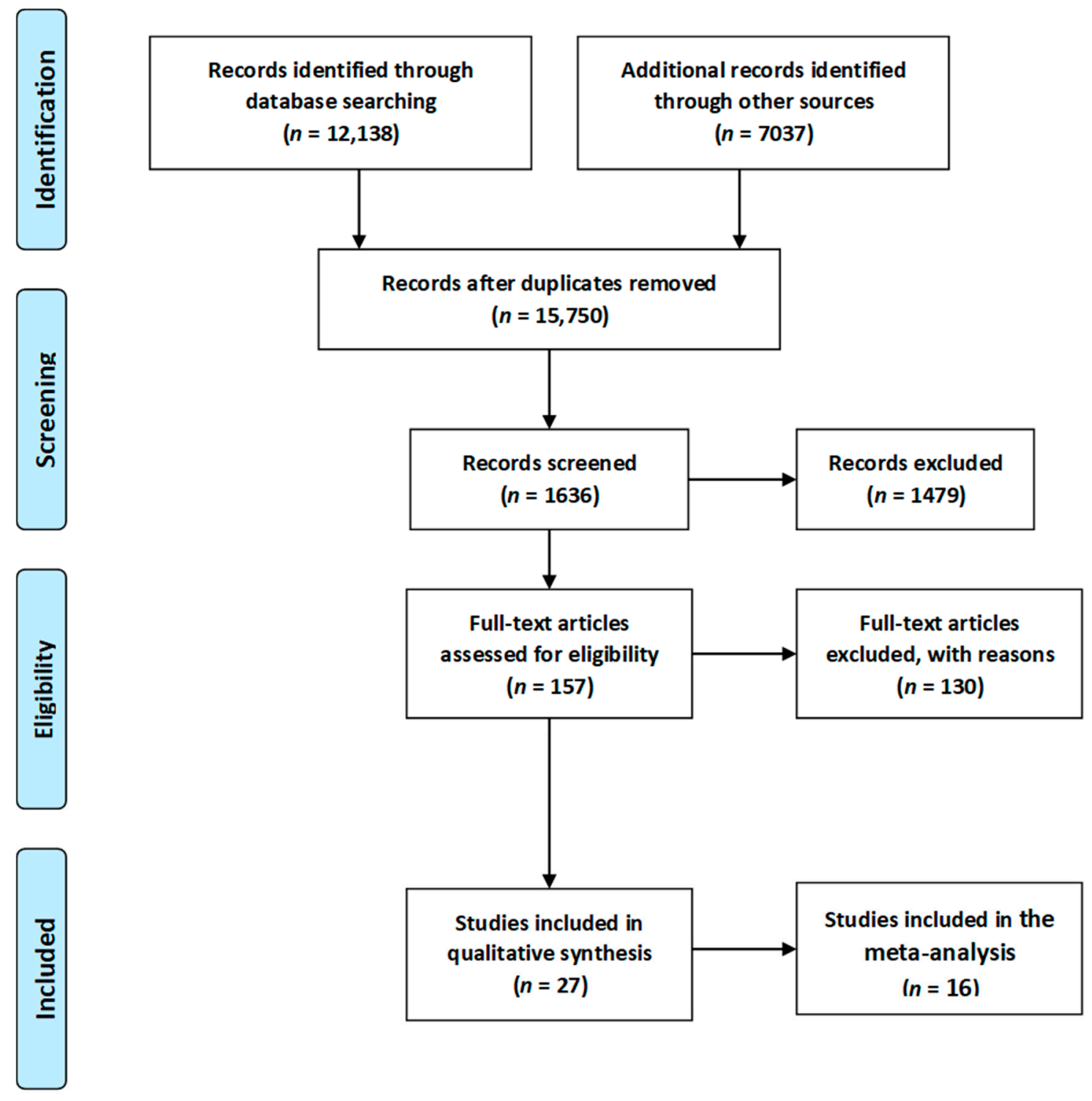

Figure 2. Flow chart presenting the process of searching for the eligible articles according to Preferred Reporting Items for Systematic Reviews and Meta-Analyses (PRISMA) guidelines [90]. 


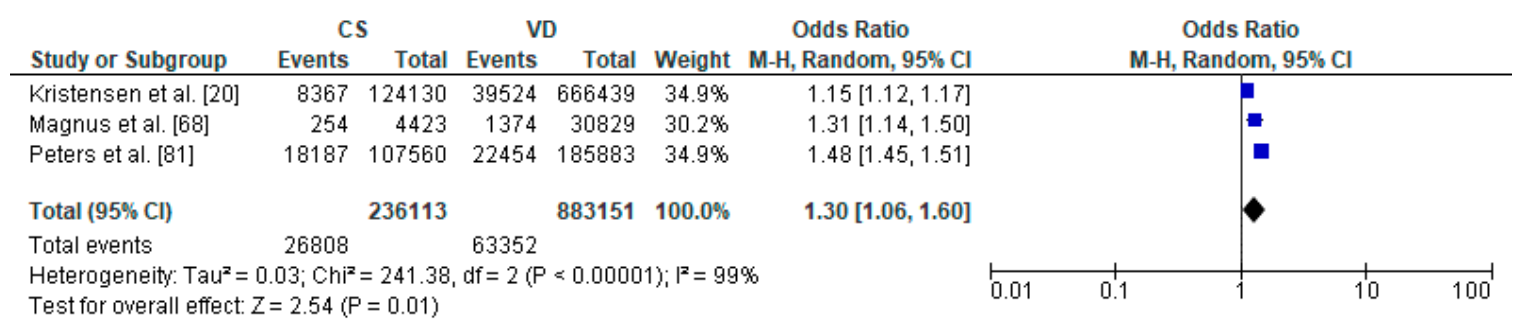

Figure 3. Forest plot for respiratory tract infections in the caesarean section (CS) and vaginally delivered (VD) offspring. M.-H.-Mantel-Haenszel; CI-confidence interval; $\mathrm{I}^{2}$-heterogeneity; df-degrees of freedom.

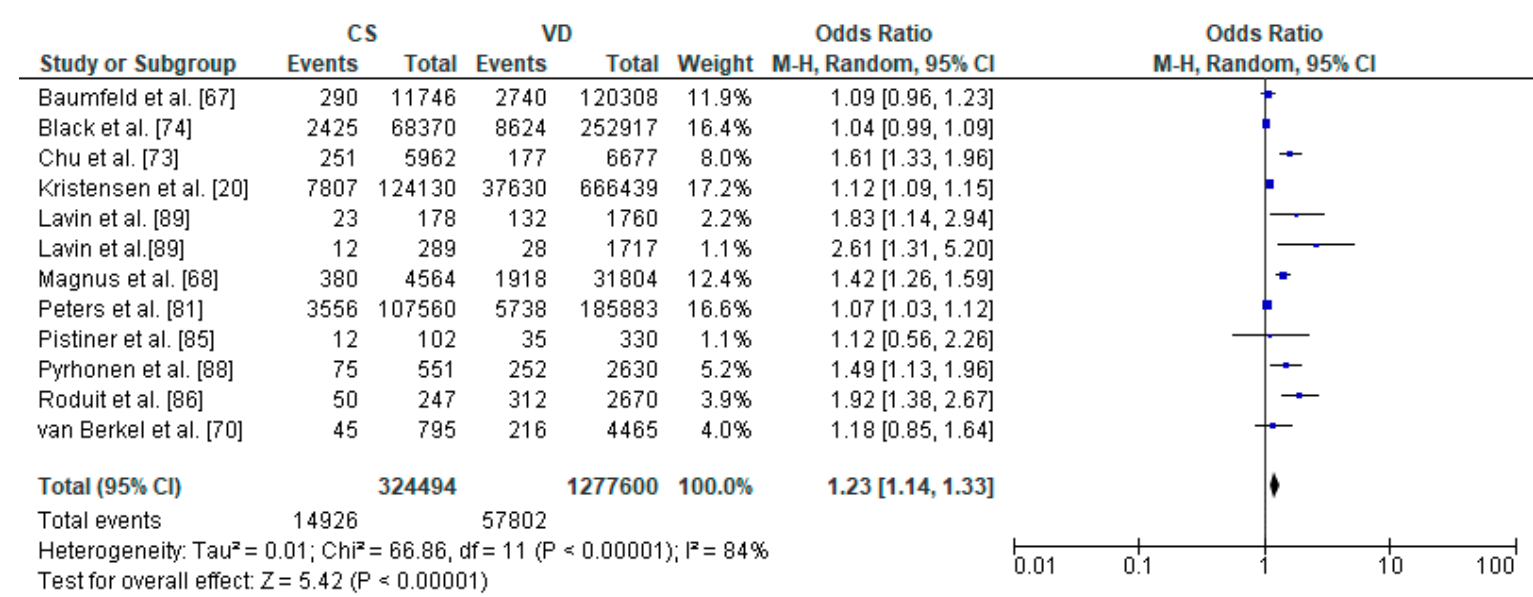

Figure 4. Forest plot for asthma in the caesarean section (CS) and vaginally delivered (VD) offspring. M.-H.-Mantel-Haenszel; CI-confidence interval; $\mathrm{I}^{2}$-heterogeneity; df-degrees of freedom.

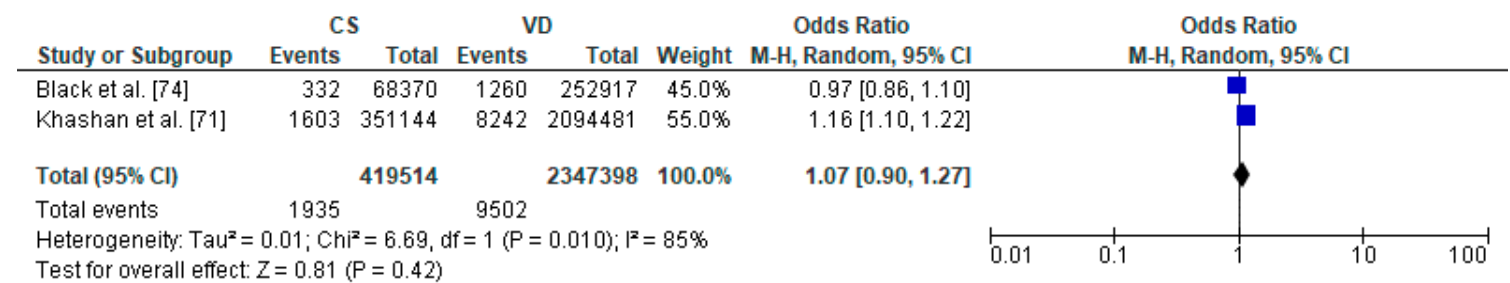

Figure 5. Forest plot for diabetes mellitus type 1 in the caesarean section (CS) and vaginally delivered (VD) offspring. M.-H.-Mantel-Haenszel; CI-confidence interval; $\mathrm{I}^{2}$-heterogeneity; df-degrees of freedom.

\begin{tabular}{|c|c|c|c|c|c|c|c|c|c|c|}
\hline Study or Subgroup & \multicolumn{2}{|l|}{ CS } & \multicolumn{2}{|l|}{ VD } & \multicolumn{3}{|c|}{ Odds Ratio } & \multicolumn{2}{|c|}{$\begin{array}{c}\text { Odds Ratio } \\
\text { M-H, Random, } 95 \% \mathrm{Cl}\end{array}$} & \\
\hline Black et al. [74] & 1999 & 16097 & 4592 & 48886 & $66.4 \%$ & $1.37[1.29,1.45]$ & & & $\square$ & \\
\hline Masukume et al. [80]* & 85 & 3872 & 245 & 14244 & $3.3 \%$ & $1.28[1.00,1.65]$ & & & $\rightarrow$ & \\
\hline Mesquita et al. [76] & 247 & 661 & 434 & 1402 & $5.5 \%$ & $1.33[1.10,1.62]$ & & & $\rightarrow$ & \\
\hline Steur et al. [79] & 30 & 145 & 205 & 1542 & $1.1 \%$ & $1.70[1.11,2.61]$ & & & & \\
\hline Yuan et al. [75] & 754 & 3544 & 2012 & 11727 & $23.6 \%$ & $1.30[1.19,1.43]$ & & & 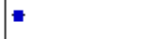 & \\
\hline Total $(95 \% \mathrm{Cl})$ & & 24319 & & 77801 & $100.0 \%$ & $1.35[1.29,1.41]$ & & & 1 & \\
\hline Total events & 3115 & & 7488 & & & & & & & \\
\hline $\begin{array}{l}\text { Heterogeneity: } \operatorname{Tau}^{2}=0 \\
\text { Test for overall effect: } Z\end{array}$ & $\begin{array}{l}50 ; \mathrm{Chi}^{2}= \\
=12.96 \Leftrightarrow \mathrm{F}\end{array}$ & $\begin{array}{l}2.02, \mathrm{df} \\
<0.000\end{array}$ & $\begin{array}{l}=4(\mathrm{P}= \\
01)\end{array}$ & $0.73) ; 1^{2}$ & $=0 \%$ & & 0.01 & 0.1 & 10 & 100 \\
\hline
\end{tabular}

Figure 6. Forest plot for obesity in the caesarean section (CS) and vaginally delivered (VD) offspring. M.-H.-Mantel-Haenszel; CI-confidence interval; $\mathrm{I}^{2}$-heterogeneity; df-degrees of freedom; ${ }^{*}$-analysis for group of children at three years of age. 


\subsection{General Characteristics of the Studies Included}

Studies included in the systematic review were conducted in 5 different continents with the majority conducted in Europe $(n=18)$ in 15 different countries with the majority conducted in Sweden $(n=5)$. Twenty studies are prospective cohort while 7 are retrospective. Ten studies distinguished between types of cesarean section when reporting study results. Characteristics of studies including country, type of study design, sample size, age and assessed disorder are demonstrated in Tables 1-4.

Table 1. Characteristics of the studies analyzing the impact of cesarean section on offspring respiratory tract infections which met the inclusion criteria of both the present systematic review and meta-analysis.

\begin{tabular}{cccccc}
\hline Author & Country & Study Design & $\begin{array}{c}\text { Sample } \\
\text { Size }\end{array}$ & Age & $\begin{array}{c}\text { Assessed } \\
\text { Respiratory } \\
\text { Morbidity }\end{array}$ \\
\hline $\begin{array}{c}\text { Kristensen et al. } \\
\text { [20] }\end{array}$ & Denmark & Cohort Retrospective & 790,569 & from 0 to 14 y & $\begin{array}{c}\text { lower } \\
\text { respiratory } \\
\text { tract infection }\end{array}$ \\
\hline $\begin{array}{c}\text { Magnus et al. } \\
\text { [68] }\end{array}$ & Norway & $\begin{array}{c}\text { Cohort Prospective } \\
\text { (Norwegian Mother } \\
\text { and Child Cohort } \\
\text { Study) }\end{array}$ & 37,171 & 36 months & $\begin{array}{c}\text { recurrent lower } \\
\text { respiratory } \\
\text { tract infections }\end{array}$ \\
\hline Peters et al. [81] & Australia & Cohort Prospective & 491,590 & $\begin{array}{c}\text { in the first 28 days } \\
\text { and up to 5 y }\end{array}$ & $\begin{array}{c}\text { respiratory } \\
\text { infection }\end{array}$ \\
\hline
\end{tabular}

Table 2. Characteristics of studies included the impact of cesarean section on asthma in offspring, which met the inclusion criteria of both the present systematic review and meta-analysis.

\begin{tabular}{|c|c|c|c|c|c|}
\hline Author & Country & Study Design & $\begin{array}{l}\text { Sample } \\
\text { Size }\end{array}$ & Age & $\begin{array}{l}\text { Assessed } \\
\text { Asthma } \\
\text { Morbidity }\end{array}$ \\
\hline $\begin{array}{c}\text { Kristensen et al. } \\
{[20]}\end{array}$ & Denmark & Cohort Retrospective & 790,569 & from 0 to $14 \mathrm{y}$ & Risk of asthma \\
\hline $\begin{array}{l}\text { Baumfeld et al. } \\
\text { [67] }\end{array}$ & Israel & Cohort Retrospective & 132,054 & $18 \mathrm{y}$ & Risk of asthma \\
\hline $\begin{array}{l}\text { Magnus et al. } \\
{[68]}\end{array}$ & Norway & $\begin{array}{c}\text { Prospective } \\
\text { (Norwegian Mother } \\
\text { and Child Cohort } \\
\text { Study) }\end{array}$ & 37,171 & $3 y$ & Risk of asthma \\
\hline $\begin{array}{c}\text { van Berkel et al. } \\
{[70]}\end{array}$ & Netherlands & Cohort Prospective & 6128 & $6 y$ & Risk of asthma \\
\hline Chu et al. [73] & China & $\begin{array}{l}\text { Case-Control } \\
\text { Retrospective }\end{array}$ & 1385 & $5-12 y$ & Risk of asthma \\
\hline Black et al. [74] & UK & Cohort Retrospective & 321,287 & $5 y$ & $\begin{array}{c}\text { Asthma } \\
\text { hospitalization }\end{array}$ \\
\hline Peters et al. [81] & Australia & Cohort Prospective & 491,590 & $\begin{array}{l}\text { in the first } 28 \text { days } \\
\text { and up to } 5 y\end{array}$ & Risk of asthma \\
\hline $\begin{array}{c}\text { Pistiner et al. } \\
\text { [85] }\end{array}$ & USA & Cohort Prospective & 498 & $9 y$ & $\begin{array}{c}\text { Asthma } \\
\text { symptoms }\end{array}$ \\
\hline $\begin{array}{l}\text { Roduit et al. } \\
\text { [86] }\end{array}$ & Netherlands & Cohort Prospective & 2917 & $8 y$ & Risk of asthma \\
\hline $\begin{array}{c}\text { Pyrhonen et al. } \\
\text { [88] }\end{array}$ & Finland & Cohort Retrospective & 4779 & $4 y$ & Risk of asthma \\
\hline Lavin et al. [89] & Vietnam & Cohort Prospective & 2000 & $8 y$ & Risk of asthma \\
\hline Lavin et al. [89] & India & Cohort Prospective & 2026 & $8 y$ & Risk of asthma \\
\hline
\end{tabular}


Table 3. Characteristics of studies included the impact of cesarean section on diabetes mellitus type 1 in offspring which met the inclusion criteria of both the present systematic review and meta-analysis.

\begin{tabular}{cccccc}
\hline Author & Country & Study Design & $\begin{array}{c}\text { Sample } \\
\text { Size }\end{array}$ & Age & $\begin{array}{c}\text { Assessed Metabolic } \\
\text { Disorders }\end{array}$ \\
\hline Black et al. [74] & UK & Cohort Retrospective & 321,287 & $5 \mathrm{y}$ & diabetes mellitus type 1 \\
\hline Khashan et al. [71] & Sweden & Cohort Prospective & $2,638,083$ & $27 \mathrm{y}$ & diabetes mellitus type 1 \\
\hline
\end{tabular}

Table 4. Characteristics of studies included the impact of cesarean section on problems with body weight in offspring which met the inclusion criteria of the present systematic review.

\begin{tabular}{|c|c|c|c|c|c|}
\hline Author & Country & Study Design & $\begin{array}{l}\text { Sample } \\
\text { Size }\end{array}$ & Age & $\begin{array}{c}\text { Assessed Problems } \\
\text { with Body Weight }\end{array}$ \\
\hline Black et al. [74] & UK & Cohort Retrospective & 321,287 & $5 y$ & Obesity \\
\hline Ajslev et al. [72] & Denmark & Cohort Prospective & 28,354 & $7 y$ & Obesity \\
\hline Yuan et al. [75] & USA & Cohort Prospective & 22,068 & $20-28 y$ & Obesity \\
\hline Mesquita et al. [76] & Brazil & Cohort Prospective & 2063 & $23-25 y$ & Risk of adiposity \\
\hline Masukume et al. [77] & Ireland & $\begin{array}{l}\text { Cohort Prospective } \\
\text { (GUI study) }\end{array}$ & 11,134 & $3-5 y$ & Obesity \\
\hline Alhqvist et al. [78] & Sweden & Cohort Prospective & 97,291 & $9-12$ y & Obesity \\
\hline Steur et al. [79] & Netherlands & $\begin{array}{l}\text { Cohort Prospective } \\
\text { (PIAMA study) }\end{array}$ & 1687 & $8 \mathrm{y}$ & Overweight \\
\hline Masukume et al. [80] & UK & $\begin{array}{l}\text { Cohort Prospective } \\
\text { (MCS) }\end{array}$ & 18,827 & $14 \mathrm{y}$ & $\begin{array}{c}\text { Body mas index and } \\
\text { body fat }\end{array}$ \\
\hline
\end{tabular}

GUI-Growing Up in Ireland; PIAMA-Prevention and Incidence of Asthma and Mite Allergy; MCS- Millennium Cohort Study.

\subsection{Caesarean Section and Respiratory Tract Infections-Meta-Analysis}

The meta-analysis regarding the impact of caesarean section on the risk of respiratory tract infections in offspring was conducted based on 3 studies with total number of 236,113 children delivered by caesarean section and 883,151 vaginally delivered children. Children were examined within a wide range of ages, from 0 to 14 years of age (Table 1). Respiratory tract infections was significantly more common in the CS group than the VD group (pooled OR $=1.3095 \% \mathrm{CI} 1.06-1.60$, $p=0.001$ ) which indicates that caesarean section increased the risk of respiratory tract infections in offspring (Figure 3). No publication bias was found for this analysis [Egger's test ( $p=0.915$ ); Begg's test (Kendall's Tau $=-0.33, \mathrm{p}=0.601$ )]. The results of the meta-analysis were found stable after performing sensitivity analysis.

\subsection{Caesarean Section and Asthma-Meta-Analysis}

The relation between caesarean section and asthma in offspring was performed in meta-analysis based on 11 studies. The study by Lavin et al. [89] analyzed caesarean section within two populations, India and Vietnam which were analyzed separately. Total number of included children delivered by caesarean section were 1,791,855 and 1,277,620 vaginally delivered children. Children were examined within a wide range of age, from 0 to 18 years of age, most commonly at the age of 8 years. The authors of the included studies focused their attention on risk of asthma, asthma hospitalization and asthma symptoms (Table 2). The random effect models analysis revealed that asthma was significantly more common in the CS group than the VD group (pooled OR $=1.2395 \% \mathrm{CI} 1.14-1.33, p<0.00001$ ) which indicates that caesarean section may be a risk factor for asthma in offspring (Figure 4). The results of publication bias tests indicated that there might be potential publication bias in studies on the relationship between CS and asthma [Egger's test $(\mathrm{R}=2.03, p=0.024)$; Begg's test (Kendall's Tau $=0.15$, $p=0.493)$ ]. The bias was not present when the results by Lavin et al. study [89] performed in 
Vietnam population were removed [Egger's test $(\mathrm{R}=1.94, p=0.051)$; Begg's test (Kendall's Tau $=0.13$, $p=0.586)]$.

\subsection{Caesarean Section and Diabetes Mellitus Type 1-Meta-Analysis}

To the meta-analysis on the relation between caesarean section and diabetes mellitus type 1 in offspring 2 studies were included with a total number of 419,514 children delivered by caesarean section and 2,347,398 vaginally delivered children. The age of children examined ranged from the first 5 years to 27 years (Table 3 ). The present meta-analysis showed that diabetes mellitus type 1 did not significantly differ between CS and VD groups thus caesarean section does not increase the risk factor of metabolic disorders in offspring (pooled OR $=1.0795 \%$ CI $0.90-1.27, p=0.2$ ) (Figure 5). Due to fact that analysis was based only on two studies, both publication bias as well as sensitivity analysis were not performed and thus the results must be treated with caution.

\subsection{Caesarean Section and Increased Body Weight-Meta-Analysis}

The pooled OR for relation between caesarean section and increased body weight in offspring was analyzed for 5 studies, out of 8 articles which met the inclusion criteria of the present systematic review: a total number of 24,319 children delivered by caesarean section and 77,801 vaginally delivered children. The age of children examined ranged from 5 years to 28 years. The authors of the included studies focused their attention on overweight, obesity, risk of adiposity and body mass index and body fat (Table 4). The present meta-analysis demonstrated that increased body weight was significantly more common in the CS group than the VD group thus caesarean section may be a risk factor of obesity in offspring (pooled OR $=1.3595 \% \mathrm{CI} 1.29-1.41, p<0.00001$ ) (Figure 6). No publication bias was found for this analysis [Egger's test $(\mathrm{R}=0.12, p=0.863)$; Begg's test (Kendall's Tau $=0.20, p=0.624)$ ] and sensitivity analysis revealed stability of the results.

\section{Discussion}

The stimulation of the hypothalamic-pituitary-adrenal axis (HPA) in the fetus leads to the increase in stress hormones contributing to lung maturation [91], thereby reducing the postnatal manifestations of respiratory insufficiency [92]. Another analysis of a multicenter World Health Organization Multicounty Survey on Maternal and Newborn Health (WHOMCS) revealed that cesarean section increased morbidity in neonates [93]. The most common complications listed by researchers include respiratory disorders, transient tachypnea or postpartum hypoglycemia $[94,95]$. The frequency of those complications was influenced by the co-existence of childbirth which significantly decreased the occurrence rates of such disorders $[66,96]$. In the case of an elective cesarean section, the risk of respiratory morbidity including transient tachypnea of the newborn (TTN), respiratory distress syndrome (RDS), and persistent pulmonary hypertension (PPH) at 37 weeks of gestation reached $10 \%$, while with vaginal delivery the risk was $2.8 \%$ [67]. Previously, infants delivered by caesarean section were demonstrated to have significantly lower compliance of the respiratory system at the age of 1 year than those after vaginal delivery [22]. The authors however, did not observe differences in the resistance of the respiratory system and maximal expiratory flow at functional residual capacity between the groups depending on the type of delivery. Hansen et al. [66] reported that the percentage of complications was affected by cesarean section procedures and by the duration of the pregnancy. The risk of developing RDS after cesarean section at 37 gestational weeks increased 4-fold (odds ratio (OR) $3.9,95 \%$ confidence interval 2.4 to 6.5 ), while at 39 weeks it was half lower (OR 1.9, 95\% confidence interval (CI) 1.2 to 3.0) [66]. Similar conclusions were reached following an Israel study including 132,054 cases. Hospitalizations of offspring involving respiratory morbidity were significantly common in offspring delivered caesarean section $(5.2 \%$ vs. $4.3 \%$ in vaginal deliveries [67]. Table 1 presents characteristics of studies regarding the impact of cesarean section on offspring respiratory morbidity. Currently, a prophylactic dose of corticosteroids is used in everyday clinical practice in order to avoid respiratory complications associated with elective cesarean section and premature delivery [97-99]. 
Numerous epidemiological studies demonstrated a correlation between cesarean section and an increased risk of developing immune diseases, including bronchial asthma [68-70,100], allergic rhinitis [101], ulcerative colitis, type 1 diabetes mellitus [17,71], celiac disease [102] and obesity [72,103]. Chu et al. [73] studied the risk of developing asthma and allergic rhinitis in case of cesarean section without medical indications. The authors reported that children delivered by cesarean section significantly more often develop asthma and allergic rhinitis [73]. Similar results were obtained in a meta-analysis conducted in 2018, which revealed a significantly higher risk of developing asthma up to the age of 12 years (OR 1.21, 13 studies, $\mathrm{n}=887,960$ ) and obesity up to the age of 5 years (OR 1.59, $95 \%$ CI 1.33-1.90; $\mathrm{n}=64,113 ; 6$ studies) in children delivered by cesarean section [23]. Comparable results concerning asthma were revealed by a meta-analysis conducted by Darabi et al. [104]. It needs to be emphasized that the above mentioned studies included the analyses of cesarean sections without considering the clinical indications for performing the procedure. Black et al. compared emergency cesarean section with elective c-section and found no significantly different risk of asthma and obesity at age 5 year, however, authors noticed increased risk of developing type 1 diabetes $(0.66 \%$ vs. $0.44 \%$; difference $0.22 \%$ [ $95 \%$ CI $0.13-0.31 \%]$ ] [74]. A prospective study conducted in the United States included over 22,000 participants and showed a 13\% cumulative risk of developing obesity in children delivered by cesarean section. The authors emphasized that the risk of developing obesity in children delivered by cesarean section increased up to $64 \%$ compared to their siblings who were delivered vaginally [75]. Mesquita et al. demonstrated that the prevalence of obesity in children delivered by cesarean section was 33\% higher and in a group of 19 -year olds it increased to $50 \%$ compared to their vaginally delivered peers [76]. Another European cohort study confirmed the correlation between cesarean section and the risk of developing obesity in children at the age of 3 . However, the fact was only observable in a group of acute cesarean sections (adjusted relative risk ratio (aRRR) $=1.23 ; 95 \%$ CI 1.04-1.44), but not elective ones (aRRR $=1.06$; 95\% CI 0.90-1.25) [77]. Basing on the obtained results the issue of the participation of the microbiota in the development of obesity should be further discussed [51]. Ahlqvist, et al. [78] found no evidence of an association between elective or nonelective cesarean section and young adulthood obesity in young male conscripts when accounting for maternal and paternal factors (relative risk ratio RRR $=0.96$; CI 95\% 0.83-1.10). Authors suggested there is no clinically relevant association between cesarean section and the development of obesity. The PIAMA study indicated an increased risk of obesity $(\mathrm{OR}=1.7)$ [79] while a long-term prospective study conducted in the United Kingdom showed no significant correlation between elective cesarean section and both body mass index (BMI), as well as body fat percentage ( $\mathrm{BF} \%$ ) in children [80]. The results of the remaining studies concerning the risk of developing other immune diseases are also ambiguous. A European prospective study comprising over 320,000 participants showed no significant differences in the prevalence of obesity and asthma in children aged up to 5 years delivered by cesarean section regardless of the manifestations of concomitant childbirth. Moreover, the authors did not confirm significant differences regarding the frequency of obesity, intestinal inflammation, and type 1 diabetes between a group of children delivered vaginally and by elective cesarean section [74]. Another study conducted in Australia showed that children delivered by cesarean section significantly more frequently developed infections, eczemas or metabolic diseases. However, the highest risk of metabolic diseases was present in case of acute cesarean sections (OR 2.63, 95\% CI 2.26-3.07) [81]. An American, prospective cohort study compered the incidence of obesity and type 2 diabetes between birth by cesarean and vaginal delivery among 33226 women participating in the Nurses' Health Study II, who were born between 1946-1964, with follow up through the end of the 2013-2015 follow-up cycle indicated a relative risk of obesity and type 2 diabetes among women born by cesarean (OR 1.11; 95\% CI 1.03-1.19 and HR 1.46; 95\% CI 1.18-1.81) [105]. Tables 2-4 shows characteristics of studies in regard to the impact of cesarean section on offspring asthma, obesity and diabetes mellitus type 1 .

Cesarean section is supposed to protect the neonate and its neurological consequences may differ depending on obstetric indications. In case of an elective cesarean section performed because of breech presentation or a fetal-pelvic disproportion both the mother and the fetus are subjected to limited stress 
unlike with intrapartum acute cesarean section. Animal research attracted attention to behavioral disorders of the offspring of females who had undergone cesarean section [106]. However, studies concerning children delivered by cesarean section demonstrated contradictory results, which assessed the prevalence of autism spectrum disorders (ASD), ADHD or behavioral disorders [82,107], especially if the analyses comprised the effect of environmental factors. A meta-analysis of the neurological consequences of surgical deliveries published in 2019 confirmed a higher risk of developing autism spectrum disorders (OR 1.33; 95\% CI, 1.25-1.41) and ADHD (OR 1.17; 95\% CI, 1.07-1.26) in children delivered by cesarean section. However, findings concerning intellectual deficits, obsessive-compulsive disorders, tics and eating disorders were not so explicit. The study based on 300 children at pre-school age reported that mode of delivery has no impact on IQ score [108]. In turn, the study performed in sizeable group of 5000 pre-school children showed that children delivered by caesarean section had significantly higher IQ test scores. However, the authors observed no significant difference in IQ scores between caesarean delivery and natural vaginal delivery groups after adjusting of among others maternal and paternal education, maternal age and parity [109]. Zhang et al. [110] reported no correlation between the procedure of cesarean section and the risk of developing depression, affective and non-affective psychosis. On the other hand, Baumfeld et al. conducted a prospective cohort study and demonstrated that cesarean section was an independent factor affecting neurological disorders in children along with birth weight, maternal age, Apgar score, gestational age and the sex of the neonate [83]. Recent data by Sadowska et al. [84] demonstrated that delivery by cesarean section increased the risk of epilepsy over two-fold (OR 2.17) in the patients with cerebral palsy. Deoni et al. [111] demonstrated for the first time that caesarean section may be related with changes in brain development, at least during early infancy. The authors observed delivery mode-related differences in white matter development during infancy, which involved the frontal, temporal, and parietal lobes as well as corpus callosum. Children delivered by cesarean section showed significantly lower white matter development in widespread brain regions and simultaneously lower functional connectivity in the brain [112].

\section{Study Limitations}

A considerable amount of research concerning the issue of cesarean sections includes retrospective studies which do not comprise clinical indications for a surgical procedure [86-89] and do not refer to data regarding the duration of amniotic fluid leakage, the presence of uterine contractions and a history of fertility treatment. Furthermore, there are differences in the definitions of acute or intrapartum cesarean section. Few authors tackled the issue of the biochemical and radiological test results, which would facilitate the objectification of the postnatal status of a newborn.

\section{Conclusions}

This systematic review of literature and meta-analysis shows, that cesarean section may be associated with several pediatric complications. The results of the studies included indicated that children delivered by cesarean section more commonly developed respiratory tract infections, obesity and the manifestations of asthma than children delivered vaginally. The risk of developing diabetes mellitus type 1 or neurological disorders in offspring after caesarean section is still under discussion. Due to a high number of reciprocally exclusive study results concerning long-term pediatric sequelae it is recommended to conduct a multicenter prospective study comprising the concept of epigenetic influence of cesarean section.

Author Contributions: All authors qualified for authorship by having contributed substantially to the present study. A.S.-J. contributed to the study conceptualization, data collection and analysis, and manuscript writing. J.K.S., M.C. contributed to the data collection. B.S.-H. contributed to data collection and statistical analyses. G.J. contributed to the study conceptualization. All authors have approved the submitted version and have agreed to be accountable for all its contents. All authors have read and agreed to the published version of the manuscript.

Funding: This research received no external funding. 
Conflicts of Interest: The authors declare that they have no conflicts of interest.

\section{References}

1. Betrán, A.P.; Ye, J.; Moller, A.-B.; Zhang, J.; Gülmezoglu, A.M.; Torloni, M.R. The Increasing Trend in Caesarean Section Rates: Global, Regional and National Estimates: 1990-2014. PLoS ONE 2016, 11, e0148343. [CrossRef] [PubMed]

2. Molina, G.; Weiser, T.G.; Lipsitz, S.R.; Esquivel, M.M.; Uribe-Leitz, T.; Azad, T.; Shah, N.; Semrau, K.; Berry, W.R.; Gawande, A.A.; et al. Relationship Between Cesarean Delivery Rate and Maternal and Neonatal Mortality. JAMA 2015, 314, 2263-2270. [CrossRef] [PubMed]

3. Betran, A.P.; Torloni, M.R.; Zhang, J.J.; Gulmezoglu, A.M. WHO Working Group on Caesarean Section WHO Statement on Caesarean Section Rates. BJOG Int. J. Obstet. Gynaecol. 2015, 123, 667-670. [CrossRef] [PubMed]

4. Ye, J.; Betran, A.P.; Vela, M.G.; Souza, J.P.; Zhang, J. Searching for the Optimal Rate of Medically Necessary Cesarean Delivery. Birth 2014, 41, 237-244. [CrossRef] [PubMed]

5. Betran, A.P.; Torloni, M.R.; Zhang, J.; Ye, J.; Mikolajczyk, R.; Deneux-Tharaux, C.; Oladapo, O.T.; Souza, J.P.; Tunçalp, Ö.; Vogel, J.P.; et al. What is the optimal rate of caesarean section at population level? A systematic review of ecologic studies. Reprod. Health 2015, 12, 1-10. [CrossRef] [PubMed]

6. WHO. World Health Organization. Available online: www.who.int/reproductivehealth/ (accessed on 6 September 2020).

7. Wax, J.R.; Cartin, A.; Pinette, M.G.; Blackstone, J. Patient Choice Cesarean: An Evidence-Based Review. Obstet. Gynecol. Surv. 2004, 59, 601-616. [CrossRef] [PubMed]

8. Ecker, J. Elective Cesarean Delivery on Maternal Request. JAMA 2013, 309, 1930-1936. [CrossRef]

9. UN-IGME. Levels and Trends in Child Mortality: Report 2018. Estimates Developed by the UN Inter-Agency Group for Child Mortality Estimation. New York, NY: UN Children's Fund. 2018. Available online: https://www.unicef.org/publications/files/Child_Mortality_Report_2018.pdf (accessed on 6 September 2020).

10. Bishop, D.; Dyer, R.A.; Maswime, S.; Rodseth, R.N.; Van Dyk, D.; Kluyts, H.-L.; Tumukunde, J.T.; Madzimbamuto, F.D.; Elkhogia, A.M.; Ndonga, A.K.N.; et al. Maternal and neonatal outcomes after caesarean delivery in the African Surgical Outcomes Study: A 7-day prospective observational cohort study. Lancet Glob. Health 2019, 7, e513-e522. [CrossRef]

11. Curran, E.A.; Dalman, C.; Kearney, P.M.; Kenny, L.C.; Cryan, J.F.; Dinan, T.G.; Khashan, A.S. Association Between Obstetric Mode of Delivery and Autism Spectrum Disorder. JAMA Psychiatry 2015, 72, $935-942$. [CrossRef]

12. O’Neill, S.M.; Curran, E.A.; Dalman, C.; Kenny, L.C.; Kearney, P.M.; Clarke, G.; Cryan, J.F.; Dinan, T.G.; Khashan, A.S. Birth by Caesarean Section and the Risk of Adult Psychosis: A Population-Based Cohort Study. Schizophr. Bull. 2015, 42, 633-641. [CrossRef]

13. Hyde, M.J.; Modi, N. The long-term effects of birth by caesarean section: The case for a randomised controlled trial. Early Hum. Dev. 2012, 88, 943-949. [CrossRef]

14. Thavagnanam, S.; Fleming, J.; Bromley, A.; Shields, M.; Cardwell, C. A meta-analysis of the association between Caesarean section and childhood asthma. Clin. Exp. Allergy 2008, 38, 629-633. [CrossRef] [PubMed]

15. Dahlen, H.G.; Downe, S.; Wright, M.L.; Kennedy, H.P.; Taylor, J.Y. Childbirth and consequent atopic disease: Emerging evidence on epigenetic effects based on the hygiene and EPIIC hypotheses. BMC Pregnancy Childbirth 2016, 16, 4. [CrossRef]

16. Decker, E.; Engelmann, G.; Findeisen, A.; Gerner, P.; Laass, M.; Ney, D.; Posovszky, C.; Hoy, L.; Hornef, M.W. Cesarean Delivery Is Associated With Celiac Disease but Not Inflammatory Bowel Disease in Children. Pediatrics 2010, 125, e1433-e1440. [CrossRef] [PubMed]

17. Cardwell, C.; Stene, L.C.; Joner, G.; Cinek, O.; Svensson, J.; Goldacre, M.J.; Parslow, R.C.; Pozzilli, P.; Brigis, G.; Stoyanov, D.; et al. Caesarean section is associated with an increased risk of childhood-onset type 1 diabetes mellitus: A meta-analysis of observational studies. Diabetologia 2008, 51, 726-735. [CrossRef] [PubMed]

18. Sevelsted, A.; Stokholm, J.; Bønnelykke, K.; Bisgaard, H. Cesarean Section and Chronic Immune Disorders. Obstet. Gynecol. Surv. 2015, 70, 303-305. [CrossRef]

19. Sinha, A.; Bewley, S. The harmful consequences of prelabour caesarean section on the baby. Obstet. Gynaecol. Reprod. Med. 2012, 22, 54-56. [CrossRef] 
20. Kristensen, K.; Henriksen, L. Cesarean section and disease associated with immune function. J. Allergy Clin. Immunol. 2016, 137, 587-590. [CrossRef]

21. Elbay, A.; Celik, U.H.; Celik, B.; Ozer, O.F.; Kilic, G.; Akkan, J.C.U.; Bayraktar, B.T.; Kaymak, N.Z. Intraocular pressure in infants and its association with hormonal changes with vaginal birth versus cesarean section. Int. Ophthalmol. 2016, 36, 855-860. [CrossRef]

22. Liao, S.-L.; Tsai, M.-H.; Yao, T.-C.; Hua, M.-C.; Yeh, K.-W.; Chiu, C.-Y.; Su, K.-W.; Huang, S.-Y.; Kao, C.-C.; Lai, S.-H.; et al. Caesarean Section is associated with reduced perinatal cytokine response, increased risk of bacterial colonization in the airway, and infantile wheezing. Sci. Rep. 2017, 7, 1-8. [CrossRef]

23. Keag, O.E.; Norman, J.; Stock, S.J. Long-term risks and benefits associated with cesarean delivery for mother, baby, and subsequent pregnancies: Systematic review and meta-analysis. PLoS Med. 2018, 15, e1002494. [CrossRef]

24. Nemati, B.; Atmodjo, W.; Gagnon, S.; Humes, D.; McKerlie, C.; Kaplan, F.; Sweezey, N.B. Glucocorticoid receptor disruption delays structural maturation in the lungs of newborn mice. Pediatr. Pulmonol. 2007, 43, 125-133. [CrossRef] [PubMed]

25. Rog-Zielinska, E.A.; Thomson, A.; Kenyon, C.J.; Brownstein, D.G.; Moran, C.M.; Szumska, D.; Michailidou, Z.; Richardson, J.; Owen, E.; Watt, A.; et al. Glucocorticoid receptor is required for fetal heart maturation. Hum. Mol. Genet. 2013, 22, 3269-3282. [CrossRef]

26. Schuller, C.; Känel, N.; Müller, O.; Kind, A.B.; Tinner, E.M.; Hösli, I.; Zimmermann, R.; Surbek, D. Stress and pain response of neonates after spontaneous birth and vacuum-assisted and cesarean delivery. Am. J. Obstet. Gynecol. 2012, 207, 416.e1-416.e6. [CrossRef] [PubMed]

27. Mears, K.; McAuliffe, F.; Grimes, H.; Morrison, J.J. Fetal cortisol in relation to labour, intrapartum events and mode of delivery. J. Obstet. Gynaecol. 2004, 24, 129-132. [CrossRef]

28. Vogl, S.E.; Worda, C.; Egarter, C.; Bieglmayer, C.; Szekeres, T.; Huber, J.; Husslein, P. Mode of delivery is associated with maternal and fetal endocrine stress response. BJOG Int. J. Obstet. Gynaecol. 2006, 113, 441-445. [CrossRef] [PubMed]

29. Słabuszewska-Jóźwiak, A.; Włodarczyk, M.; Kilian, K.; Rogulski, Z.; Ciebiera, M.; Szymańska-Majchrzak, J.; Zaręba, K.; Szymański, J.K.; Raczkiewicz, D.; Włodarczyk, M.; et al. Does the Caesarean Section Impact on $11 \beta$ HSD2 and Fetal Cortisol? Int. J. Environ. Res. Public Health 2020, 17, 5566. [CrossRef]

30. Sano, Y.; Doi, T.; Kikuchi, S.; Kawai, K.; Tanaka, M. Correlations between stress hormone levels in umbilical cord blood and duration of delivery. J Pak. Med. Assoc. 2015, 65, 782-784.

31. Celebi, M.; Alan, S.; Kahvecioglu, D.; Cakir, U.; Yildiz, D.; Erdeve, O.; Arsan, S.; Atasay, B. Impact of Prophylactic Continuous Positive Airway Pressure on Transient Tachypnea of the Newborn and Neonatal Intensive Care Admission in Newborns Delivered by Elective Cesarean Section. Am. J. Perinatol. 2015, 33, 99-106. [CrossRef]

32. Gizzi, C.; Klifa, R.; Pattumelli, M.; Massenzi, L.; Taveira, M.; Shankar-Aguilera, S.; De Luca, D. Continuous Positive Airway Pressure and the Burden of Care for Transient Tachypnea of the Neonate: Retrospective Cohort Study. Am. J. Perinatol. 2015, 32, 939-943. [CrossRef]

33. Azad, M.B.; Konya, T.; Maughan, H.; Guttman, D.S.; Field, C.J.; Chari, R.S.; Sears, M.R.; Becker, A.B.; Scott, J.A.; Kozyrskyj, A.L. Child Study Investigators. Gut microbiota of healthy Canadian infants: Profiles by mode of delivery and infant diet at 4 months. CMAJ 2013, 185, 385-394. [CrossRef] [PubMed]

34. Shao, Y.; Forster, S.C.; Tsaliki, E.; Vervier, K.; Strang, A.; Simpson, N.; Kumar, N.; Stares, M.D.; Rodger, A.; Brocklehurst, P.; et al. Stunted microbiota and opportunistic pathogen colonization in caesarean-section birth. Nature 2019, 574, 117-121. [CrossRef] [PubMed]

35. Makino, H.; Kushiro, A.; Ishikawa, E.; Kubota, H.; Gawad, A.; Sakai, T.; Oishi, K.; Martin, R.; Ben-Amor, K.; Knol, J.; et al. Mother-to-Infant Transmission of Intestinal Bifidobacterial Strains Has an Impact on the Early Development of Vaginally Delivered Infant's Microbiota. PLoS ONE 2013, 8, e78331. [CrossRef] [PubMed]

36. Sakwinska, O.; Foata, F.; Berger, B.; Brüssow, H.; Combremont, S.; Mercenier, A.; Dogra, S.; Soh, S.E.; Yen, J.; Heong, G.; et al. Does the maternal vaginal microbiota play a role in seeding the microbiota of neonatal gut and nose? Benef. Microbes 2017, 8, 763-778. [CrossRef]

37. Fujimura, K.E.; Slusher, N.A.; Cabana, M.D.; Lynch, S.V. Role of the gut microbiota in defining human health. Expert Rev. Anti- Infect. Ther. 2010, 8, 435-454. [CrossRef]

38. Mazmanian, S.K.; Liu, C.H.; Tzianabos, A.O.; Kasper, D.L. An Immunomodulatory Molecule of Symbiotic Bacteria Directs Maturation of the Host Immune System. Cell 2005, 122, 107-118. [CrossRef] 
39. Olszak, T.; An, D.; Zeissig, S.; Vera, M.P.; Richter, J.; Franke, A.; Glickman, J.N.; Siebert, R.; Baron, R.M.; Kasper, D.L.; et al. Microbial Exposure During Early Life Has Persistent Effects on Natural Killer T Cell Function. Science 2012, 336, 489-493. [CrossRef]

40. Arpaia, N.; Campbell, C.; Fan, X.; Dikiy, S.; Van Der Veeken, J.; DeRoos, P.; Liu, H.; Cross, J.R.; Pfeffer, K.; Coffer, P.J.; et al. Metabolites produced by commensal bacteria promote peripheral regulatory T-cell generation. Nat. Cell Biol. 2013, 504, 451-455. [CrossRef]

41. Hapfelmeier, S.; Lawson, M.A.E.; Slack, E.; Kirundi, J.K.; Stoel, M.; Heikenwalder, M.; Cahenzli, J.; Velykoredko, Y.; Balmer, M.L.; Endt, K.; et al. Reversible Microbial Colonization of Germ-Free Mice Reveals the Dynamics of IgA Immune Responses. Science 2010, 328, 1705-1709. [CrossRef]

42. Schirmer, M.; Smeekens, S.P.; Vlamakis, H.; Jaeger, M.; Oosting, M.; Franzosa, E.A.; Ter Horst, R.; Jansen, T.; Jacobs, L.; Bonder, M.J.; et al. Linking the Human Gut Microbiome to Inflammatory Cytokine Production Capacity. Cell 2016, 167, 1897. [CrossRef]

43. Young, V.B. The intestinal microbiota in health and disease. Curr. Opin. Gastroenterol. 2012, $28,63-69$. [CrossRef]

44. Maynard, C.L.; Elson, C.O.; Hatton, R.D.; Weaver, C.T. Reciprocal interactions of the intestinal microbiota and immune system. Nat. Cell Biol. 2012, 489, 231-241. [CrossRef] [PubMed]

45. Yu, J.; Jang, S.-O.; Kim, B.-J.; Song, Y.-H.; Kwon, J.-W.; Kang, M.-J.; Choi, W.-A.; Jung, H.-D.; Hong, S.-J. The Effects of Lactobacillus rhamnosus on the Prevention of Asthma in a Murine Model. Allergy Asthma Immunol. Res. 2010, 2, 199-205. [CrossRef] [PubMed]

46. Lu, C.-Y.; Ni, Y.-H. Gut microbiota and the development of pediatric diseases. J. Gastroenterol. 2015, 50, 720-726. [CrossRef] [PubMed]

47. Luoto, R.; Kalliomäki, M.; Laitinen, K.; Delzenne, N.M.; Cani, P.D.; Salminen, S.; Isolauri, E. Initial Dietary and Microbiological Environments Deviate in Normal-weight Compared to Overweight Children at 10 Years of Age. J. Pediatr. Gastroenterol. Nutr. 2011, 52, 90-95. [CrossRef]

48. Akagawa, S.; Tsuji, S.; Onuma, C.; Akagawa, Y.; Yamaguchi, T.; Yamagishi, M.; Yamanouchi, S.; Kimata, T.; Sekiya, S.-I.; Ohashi, A.; et al. Effect of Delivery Mode and Nutrition on Gut Microbiota in Neonates. Ann. Nutr. Metab. 2019, 74, 132-139. [CrossRef]

49. Montoya-Williams, D.; Lemas, D.J.; Spiryda, L.; Patel, K.; Carney, O.O.; Neu, J.; Carson, T.L. The Neonatal Microbiome and Its Partial Role in Mediating the Association between Birth by Cesarean Section and Adverse Pediatric Outcomes. Neonatology 2018, 114, 103-111. [CrossRef]

50. Tan, J.; McKenzie, C.; Potamitis, M.; Thorburn, A.N.; Mackay, C.R.; Macia, L. The Role of Short-Chain Fatty Acids in Health and Disease. Adv. Immunol. 2014, 121, 91-119. [CrossRef]

51. Begum, M.; Pilkington, R.; Chittleborough, C.; Lynch, J.; Penno, M.; Smithers, L.G. Caesarean section and risk of type 1 diabetes: Whole-of-population study. Diabet. Med. 2019, 36, 1686-1693. [CrossRef]

52. Yajnik, C.S. Early Life Origins of Insulin Resistance and Type 2 Diabetes in India and Other Asian Countries. J. Nutr. 2004, 134, 205-210. [CrossRef]

53. Barker, D.J.P. The developmental origins of chronic adult disease. Acta Paediatr. 2004, 93, 26-33. [CrossRef]

54. Painter, R.C.; Roseboom, T.J.; Bleker, O.P. Prenatal exposure to the Dutch famine and disease in later life: An overview. Reprod. Toxicol. 2005, 20, 345-352. [CrossRef] [PubMed]

55. Gluckman, P.D.; Hanson, M.A.; Beedle, A.S. Early life events and their consequences for later disease: A life history and evolutionary perspective. Am. J. Hum. Biol. 2007, 19, 1-19. [CrossRef]

56. St Clair, D.; Xu, M.; Wang, P.; Yu, Y.; Fang, Y.; Zhang, F.; Zheng, X.; Gu, N.; Feng, G.; Sham, P.; et al. Rates of adult schizophrenia. Following prenatal exposure to the Chinese famine of 1959-1961. JAMA 2005, 294, 557-562. [CrossRef]

57. Dahlen, H.; Kennedy, H.; Anderson, C.; Bell, A.; Clark, A.; Foureur, M.; Ohm, J.; Shearman, A.; Taylor, J.; Wright, M.; et al. The EPIIC hypothesis: Intrapartum effects on the neonatal epigenome and consequent health outcomes. Med. Hypotheses 2013, 80, 656-662. [CrossRef] [PubMed]

58. Moarii, M.; Boeva, V.; Vert, J.-P.; Reyal, F. Changes in correlation between promoter methylation and gene expression in cancer. BMC Genom. 2015, 16, 1-14. [CrossRef] [PubMed]

59. Becket, E.; Chopra, S.; Duymich, C.E.; Lin, J.J.; You, J.S.; Pandiyan, K.; Nichols, P.W.; Siegmund, K.D.; Charlet, J.; Weisenberger, D.J.; et al. Identification of DNA Methylation-Independent Epigenetic Events Underlying Clear Cell Renal Cell Carcinoma. Cancer Res. 2016, 76, 1954-1964. [CrossRef] [PubMed] 
60. Odom, L.N.; Taylor, H.S. Environmental induction of the fetal epigenome. Expert Rev. Obstet. Gynecol. 2010, 5, 657-664. [CrossRef]

61. Oberlander, T.F.; Weinberg, J.; Papsdorf, M.; Grunau, R.; Misri, S.; Devlin, A.M. Prenatal exposure to maternal depression, neonatal methylation of human glucocorticoid receptor gene (NR3C1) and infant cortisol stress responses. Epigenetics 2008, 3, 97-106. [CrossRef]

62. Breton, C.V.; Byun, H.-M.; Wenten, M.; Pan, F.; Yang, A.; Gilliland, F.D. Prenatal Tobacco Smoke Exposure Affects Global and Gene-specific DNA Methylation. Am. J. Respir. Crit. Care Med. 2009, 180, 462-467. [CrossRef]

63. Schlinzig, T.; Johansson, S.; Gunnar, A.; Ekström, T.J.; Norman, M. Epigenetic modulation at birth-altered DNA-methylation in white blood cells after Caesarean section. Acta Paediatr. 2009, 98, 1096-1099. [CrossRef] [PubMed]

64. Słabuszewska-Jóźwiak, A.; Włodarczyk, M.; Ciebiera, M.; Zwolińska, J.; Wojtyła, C.; Nowicka, G.; Jakiel, G.; Raczkiewicz, D. Placental DNA methylation in caesarean sections-A pilot study. Arch. Med. Sci. 2020, 16. [CrossRef]

65. Franz, M.B.; Poterauer, M.; Elhenicky, M.; Stary, S.; Birner, P.; Vinatzer, U.; Husslein, P.; Streubel, B.; Husslein, H. Global and single gene DNA methylation in umbilical cord blood cells after elective caesarean: A pilot study. Eur. J. Obstet. Gynecol. Reprod. Biol. 2014, 179, 121-124. [CrossRef]

66. Hansen, A.K.; Wisborg, K.; Uldbjerg, N.; Henriksen, T.B. Risk of respiratory morbidity in term infants delivered by elective caesarean section: Cohort study. BMJ 2007, 336, 85-87. [CrossRef] [PubMed]

67. Yael, B.; Walfisch, A.; Wainstock, T.; Segal, I.; Sergienko, R.; Landau, D.; Sheiner, E. Elective cesarean delivery at term and the long-term risk for respiratory morbidity of the offspring. Eur. J. Nucl. Med. Mol. Imaging 2018, 177, 1653-1659. [CrossRef]

68. Magnus, M.C.; Håberg, S.E.; Stigum, H.; Nafstad, P.; London, S.J.; Vangen, S.; Nystad, W. Delivery by Cesarean Section and Early Childhood Respiratory Symptoms and Disorders: The Norwegian Mother and Child Cohort Study. Am. J. Epidemiol. 2011, 174, 1275-1285. [CrossRef]

69. Almqvist, C.; Cnattingius, S.; Lichtenstein, P.; Lundholm, C. The impact of birth mode of delivery on childhood asthma and allergic diseases-A sibling study. Clin. Exp. Allergy 2012, 42, 1369-1376. [CrossRef]

70. Van Berkel, A.C.; Dekker, H.T.D.; Jaddoe, V.W.V.; Reiss, I.; Gaillard, R.; Hofman, A.; De Jongste, J.C.; Duijts, L. Mode of delivery and childhood fractional exhaled nitric oxide, interrupter resistance and asthma: The Generation R study. Pediatr. Allergy Immunol. 2015, 26, 330-336. [CrossRef]

71. Khashan, A.S.; Kenny, L.C.; Lundholm, C.; Kearney, P.M.; Gong, T.; Almqvist, C. Mode of Obstetrical Delivery and Type 1 Diabetes: A Sibling Design Study. Pediatrics 2014, 134, e806-e813. [CrossRef]

72. Ajslev, T.A.; Andersen, C.S.; Gamborg, M.; Sorensen, T.I.; Jess, T. Childhood overweight after establishment of the gut microbiota: The role of delivery mode, pre-pregnancy weight and early administration of antibiotics. Int. J. Obes. 2011, 35, 522-529. [CrossRef]

73. Chu, S.; Zhang, Y.; Jiang, Y.; Sun, W.; Zhu, Q.; Wang, B.; Jiang, F.; Zhang, J. Cesarean section without medical indication and risks of childhood allergic disorder, attenuated by breastfeeding. Sci. Rep. 2017, 7, 1-7. [CrossRef] [PubMed]

74. Black, M.; Bhattacharya, S.; Philip, S.; Norman, J.E.; McLernon, D.J. Planned Cesarean Delivery at Term and Adverse Outcomes in Childhood Health. JAMA 2015, 314, 2271-2279. [CrossRef] [PubMed]

75. Yuan, C.; Gaskins, A.J.; Blaine, A.I.; Zhang, C.; Gillman, M.W.; Missmer, S.A.; Field, A.E.; Chavarro, J.E. Association Between Cesarean Birth and Risk of Obesity in Offspring in Childhood, Adolescence, and Early Adulthood. JAMA Pediatr. 2016, 170, e162385. [CrossRef]

76. Mesquita, D.N.; Barbieri, M.A.; Goldani, H.A.; Cardoso, V.C.; Goldani, M.Z.; Kac, G.; Silva, A.A.; Bettiol, H. Cesarean section is associated with in- creased peripheral and central adiposity in young adulthood: Cohort study. PLoS ONE 2013, 8, e66827. [CrossRef]

77. Masukume, G.; O’Neill, S.M.; Baker, P.N.; Kenny, L.C.; Morton, S.M.B.; Khashan, A.S. The Impact of Caesarean Section on the Risk of Childhood Overweight and Obesity: New Evidence from a Contemporary Cohort Study. Sci. Rep. 2018, 8, 15113. [CrossRef]

78. Ahlqvist, V.H.; Persson, M.; Magnusson, C.; Berglind, D. Elective and nonelective cesarean section and obesity among young adult male offspring: A Swedish population-based cohort study. PLoS Med. 2019, 16, e1002996. [CrossRef] [PubMed] 
79. Steur, M.; Smit, H.A.; Schipper, C.M.A.; Scholtens, S.; Kerkhof, M.; De Jongste, J.C.; Haveman-Nies, A.; Brunekreef, B.; Wijga, A.H. Predicting the risk of newborn children to become overweight later in childhood: The PIAMA birth cohort study. Pediatr. Obes. 2011, 6, e170-e178. [CrossRef]

80. Masukume, G.; Khashan, A.S.; Morton, S.M.B.; Baker, P.N.; Kenny, L.C.; McCarthy, F.P. Caesarean section delivery and childhood obesity in a British longitudinal cohort study. PLoS ONE 2019, 14, e0223856. [CrossRef] [PubMed]

81. Peters, L.L.; Rm, C.T.; Jong, E.I.F.-D.; Khashan, A.; Tracy, M.; Downe, S.; Rm, E.I.F.J.; Rm, H.G.D. The effect of medical and operative birth interventions on child health outcomes in the first 28 days and up to 5 years of age: A linked data population-based cohort study. Birth 2018, 45, 347-357. [CrossRef]

82. Curran, E.A.; Khashan, A.S.; Dalman, C.; Kenny, L.C.; Cryan, J.F.; Dinan, T.G.; Kearney, P.M. Obstetric mode of delivery and attention-deficit/hyperactivity disorder: A sibling-matched study. Int. J. Epidemiol. 2016, 45, 532-542. [CrossRef]

83. Sheiner, E.; Wainstock, T.; Segal, I.; Sergienko, R.; Landau, D.; Walfisch, A.; Yael, B. Elective Cesarean Delivery at Term and the Long-Term Risk for Neurological Morbidity of the Offspring. Am. J. Perinatol. 2018, 35, 1038-1043. [CrossRef] [PubMed]

84. Sadowska, M.; Sarecka-Hujar, B.; Kopyta, I. Evaluation of Risk Factors for Epilepsy in Pediatric Patients with Cerebral Palsy. Brain Sci. 2020, 10, 481. [CrossRef]

85. Pistiner, M.; Gold, D.R.; Abdulkerim, H.; Hoffman, E.B.; Celedón, J.C. Birth by cesarean section, allergic rhinitis, and allergic sensitization among children with a parental history of atopy. J. Allergy Clin. Immunol. 2008, 122, 274-279. [CrossRef]

86. Roduit, C.; Scholtens, S.; De Jongste, J.C.; Wijga, A.H.; Gerritsen, J.; Postma, D.S.; Brunekreef, B.; Hoekstra, M.O.; Aalberse, R.; Smit, H.A. Asthma at 8 years of age in children born by caesarean section. Thorax 2009, 64, 107-113. [CrossRef]

87. Menezes, A.M.B.; Hallal, P.C.; Matijasevich, A.M.; Barros, A.J.D.; Horta, B.L.; Araujo, C.L.P.; Gigante, D.P.; Santos, I.S.; Minten, G.; Domingues, M.R.; et al. Caesarean sections and risk of wheezing in childhood and adolescence: Data from two birth cohort studies in Brazil. Clin. Exp. Allergy 2010, 41, 218-223. [CrossRef]

88. Pyrhönen, K.; Näyhä, S.; Hiltunen, L.; Läärä, E. Caesarean section and allergic manifestations: Insufficient evidence of association found in population-based study of children aged 1 to 4 years. Acta Paediatr. 2013, 102, 982-989. [CrossRef]

89. Lavin, T.; Franklin, P.; Preen, D.B. Association between Caesarean Delivery and Childhood Asthma in India and Vietnam. Paediatr. Périnat. Epidemiol. 2016, 31, 47-54. [CrossRef]

90. Moher, D.; Liberati, A.; Tetzlaff, J.; Altman, D.G. The PRISMA Group PRISMA 2009 Flow Diagram. PLoS Med. 2009, 6, e1000097. [CrossRef]

91. Lagercrantz, H. The good stress of being born. Acta Paediatr. 2016, 105, 1413-1416. [CrossRef]

92. Tutdibi, E.; Gries, K.; Bücheler, M.; Misselwitz, B.; Schlosser, R.L.; Gortner, L. Impact of Labor on Outcomes in Transient Tachypnea of the Newborn: Population-Based Study. Pediatrics 2010, 125, e577-e583. [CrossRef]

93. Ganchimeg, T.; Nagata, C.; Vogel, J.P.; Morisaki, N.; Pileggi-Castro, C.; Ortiz-Panozo, E.; Jayaratne, K.; Mittal, S.; Ota, E.; Souza, J.P.; et al. Optimal Timing of Delivery among Low-Risk Women with Prior Caesarean Section: A Secondary Analysis of the WHO Multicountry Survey on Maternal and Newborn Health. PLoS ONE 2016, 11, e0149091. [CrossRef]

94. Wilmink, F.A.; Hukkelhoven, C.W.; Lunshof, S.; Mol, B.W.J.; Van Der Post, J.A.; Papatsonis, D.N. Neonatal outcome following elective cesarean section beyond 37 weeks of gestation: A 7-year retrospective analysis of a national registry. Am. J. Obstet. Gynecol. 2010, 202, 250.e1-250.e8. [CrossRef] [PubMed]

95. Tita, A.T.; Landon, M.B.; Spong, C.Y.; Lai, Y.; Leveno, K.J.; Varner, M.W.; Moawad, A.H.; Caritis, S.N.; Meis, P.J.; Wapner, R.J.; et al. Eunice Kennedy Shriver NICHD Maternal-Fetal Medicine Units Network. Timing of elective repeat cesarean delivery at term and neonatal out- comes. N. Engl. J. Med. 2009, 360, 111-120. [CrossRef] [PubMed]

96. Hefny, S.M.; Hashem, A.M.T.; Abdel-Razek, A.-R.A.; Ayad, S.M. The neonatal respiratory outcome in relation to timing of elective cesarean section at 38 versus 39week gestation: A single center based study. Egypt. Pediatr. Assoc. Gaz. 2013, 61, 78-82. [CrossRef]

97. Nada, A.M.; Shafeek, M.; El Maraghy, M.; Nageeb, A.; El-Din, A.S.S.; Awad, M.; Salaheldine, A. Antenatal corticosteroid administration before elective caesarean section at term to prevent neonatal respiratory morbidity: A randomized controlled trial. Eur. J. Obstet. Gynecol. Reprod. Biol. 2016, 199, 88-91. [CrossRef] 
98. Sotiriadis, A.; Makrydimas, G.; Papatheodorou, S.; Ioannidis, J.P.; McGoldrick, E. Corticosteroids for preventing neonatal respiratory morbidity after elective caesarean section at term. Cochrane Database Syst. Rev. 2018, 8, CD006614. [CrossRef]

99. Roberts, D.; Brown, J.; Medley, N.; Dalziel, S.R. Antenatal corticosteroids for accelerating fetal lung maturation for women at risk of preterm birth. Cochrane Database Syst. Rev. 2017, 3, CD004454. [CrossRef]

100. Cho, C.E.; Norman, M. Cesarean section and development of the immune system in the offspring. Am. J. Obstet. Gynecol. 2013, 208, 249-254. [CrossRef]

101. Cotten, C.M.; Klebanoff, M.A.; Signore, C. Delivery after Previous Cesarean: Long-Term Outcomes in the Child. Semin. Perinatol. 2010, 34, 281-292. [CrossRef]

102. Mårild, K.; Stephansson, O.; Montgomery, S.M.; Murray, J.A.; Ludvigsson, J.F. Pregnancy Outcome and Risk of Celiac Disease in Offspring: A Nationwide Case-Control Study. Gastroenterology 2012, 142, 39-45.e3. [CrossRef]

103. Li, H.-T.; Zhou, Y.-B.; Liu, J.-M. The impact of cesarean section on offspring overweight and obesity: A systematic review and meta-analysis. Int. J. Obes. 2012, 37, 893-899. [CrossRef] [PubMed]

104. Darabi, B.; Rahmati, S.; Hafeziahmadi, M.R.; Badfar, G.; Azami, M. The association between caesarean section and childhood asthma: An updated systematic review and meta-analysis. Allergy Asthma Clin. Immunol. 2019, 15, 62. [CrossRef]

105. Chavarro, J.E.; Martín-Calvo, N.; Yuan, C.; Arvizu, M.; Rich-Edwards, J.W.; Michels, K.B.; Sun, Q. Association of Birth by Cesarean Delivery With Obesity and Type 2 Diabetes Among Adult Women. JAMA Netw. Open 2020, 3, e202605. [CrossRef]

106. Boksa, P.; El-Khodor, B. Birth insult interacts with stress at adulthood to alter dopaminergic function in animal models: Possible implications for schizophrenia and other disorders. Neurosci. Biobehav. Rev. 2003, 27, 91-101. [CrossRef]

107. Curran, E.A.; O’Neill, S.M.; Cryan, J.F.; Kenny, L.C.; Dinan, T.G.; Khashan, A.S.; Kearney, P.M. Research Review: Birth by caesarean section and development of autism spectrum disorder and attention-deficit/hyperactivity disorder: A systematic review and meta-analysis. J. Child Psychol. Psychiatry 2014, 56, 500-508. [CrossRef]

108. Hasab, M.F. Effect of Mode of Delivery on Children Intelligence Quotient at Pre-School Age in El-Minia City. Assiut Sci. Nurs. J. 2013, 1, 153-164. [CrossRef]

109. Khadem, N.; Khadivzadeh, T. The intelligence quotient of school aged children delivered by cesarean section and vaginal delivery. Iran. J. Nurs. Midwifery Res. 2010, 15, 135-140. [CrossRef]

110. Zhang, T.; Sidorchuk, A.; Sevilla-Cermeño, L.; Vilaplana-Pérez, A.; Chang, Z.; Larsson, H.; Mataix-Cols, D.; De La Cruz, L.F. Association of Cesarean Delivery With Risk of Neurodevelopmental and Psychiatric Disorders in the Offspring. JAMA Netw. Open 2019, 2, e1910236. [CrossRef] [PubMed]

111. Deoni, S.C.L.; Adams, S.H.; Li, X.; Badger, T.; Pivik, R.; Glasier, C.; Ramakrishnaiah, R.; Rowell, A.; Ou, X. Cesarean Delivery Impacts Infant Brain Development. Am. J. Neuroradiol. 2018, 40, 169-177. [CrossRef]

112. Macharey, G.; Toijonen, A.; Hinnenberg, P.; Gissler, M.; Heinonen, S.; Ziller, V. Term cesarean breech delivery in the first pregnancy is associated with an increased risk for maternal and neonatal morbidity in the subsequent delivery: A national cohort study. Arch. Gynecol. Obstet. 2020, 302, 85-91. [CrossRef]

Publisher's Note: MDPI stays neutral with regard to jurisdictional claims in published maps and institutional affiliations.

(C) 2020 by the authors. Licensee MDPI, Basel, Switzerland. This article is an open access article distributed under the terms and conditions of the Creative Commons Attribution (CC BY) license (http://creativecommons.org/licenses/by/4.0/). 